\title{
State-Level Analysis Aspects of Comparative Disaster Management
}

\author{
Bendegúz PAPP ${ }^{1}$
}

In international environments numerous different disaster management systems can be found, whose operation can be also varied because of their differences. Nowadays, there is no common, comprehensive analyzing model which could be adopted for describing and analyzing one state's disaster management system. Through conclusions drawn during the analysis of foreign emergency managements, the different domestic disaster risk management methods can be improved. Hence, the phrase disaster management can be defined in several ways and those approaches determine the analyzation framework of the given country, as well. For a unified interpretation, a model needs to be created which promotes the descriptive analysis. Since the topic is actual, in this paper an analysis model is presented, which can be applied in international environments, and it can also be helpful for domestic research.

Keywords: qualifying point, analysis level, theoretical model, international emergency management

\section{Introduction}

The primary purpose of this paper is to attempt to offer points for analyzing state-level disaster management systems and actions. The choice of the subject is fundamentally justified by the deficiency of methodology of general description, so the mission of this research is to create a primal analysis framework. Since disaster management expends to a quite big area, one analysis cannot cover every small detail of a state's system, the negotiated aspects offer help to a general, descriptive research.

The developed rating system gives an opportunity to the international disaster science for an ovjective comprehensive model in order to provide a point for comparison of different disaster management systems. Thereby, papers can be helped which pay attention to the emergency management of a country. Moreover, this framework can be used by students and young researchers who would like to get informed about some aspects of foreign or international disaster management.

On the mentioned subject, a rightly related question arises: why is it important to investigate the disaster relief system of different states? Due to global climate change, the number of natural disasters is rising all over the world which challenges the international disaster management. [1] Examining state-level disaster relief, individual systems can be developed, so this research has practical benefits besides broadening one's horizon. Central Europe and Hungary also struggles with more and denser extreme whethear phenomenon

Ph.D. student, National University of Public Service, Doctoral School of Police Science and Law

Enforcement; e-mail: papp.bend@gmail.com 
and its negative effects, the international scientific horizon could help the disaster relief. [2] The framework introduced here wishes to redound this development process.

\section{Definition of Concept and Interpreting Aspects}

According to the International Federation of Red Cross and Red Crescent Societies, disaster management is: "...the organization and management of resources and responsibilities for dealing with all humanitarian aspects of emergencies.” [3]

It investigates especially preparedness, response, and reconstruction, in order to reduce the disaster's effect on the society. Disaster is an event that requires resources beyond the capability of a community and requires a multiple agency response. It includes any domestic disaster or act of terrorism that:

- suddenly requires a much larger amount of blood than usual, or

- temporarily restricts or eliminates a blood collector's ability to collect, test, process and distribute blood, or

- temporarily restricts or prevents the local population from donating blood or restricts or prevents the use of the available inventory of blood products requiring immediate replacement or re-supply of the region's blood inventory from another region, or

- creates a sudden influx of donors requiring accelerated drawing of blood to meet an emergent need elsewhere. [4]

The word disaster can be defined in several ways, depending on the approach or the actual context. David Etkin negotiated the concepts of disaster in his book Disaster Theory [5] from a lot of aspects, as he tried to summarize the state-of-the-art of disaster science. Nevertheless, if we would like to construct an essential practical definition, then disaster is an event which requires the work of organizations related to disaster management system. As the definition of disaster is varied, the expression disaster management has also plenty of meanings. If a state-level disaster management is discussed, we need an accurate, exact interpretation of the concept.

The author's first goal is to create and describe three different approaches, which are necessary for understanding the principles of the analysis. Accordingly, this paper interprets disaster management in three different ways: as an organization, as an activity, and as a science.

Disaster management as an organization means a coordinating, managing, and controlling state-related organization. In different democratic countries-where this kind of central system can be found-disaster management is related to the executive power (unlike the legislative power or the head of state-related army). Therefore, it is part of the public administration, and is responsible to the Prime Minister, one or more ministries, or an administrator assigned specifically for disaster causes. This hierarchical system is related to the Ministry of the Interior in Hungary, to the Department of Home Security in the USA, and to the Minister of State for Disaster Management in Japan. The next chapter will discuss this topic in detail.

Disaster management as an activity is covered by home defense. According to Szabó [6] home defense consists of principles, organizations, activities, and other relevant factors 
which are related to defending the state from armed forces. This definitioin focuses on its military approach, for the broader concepts we need a security science approach. According to Deák [7] the subject of security can be classified in three categories: sovereignity of state, lives of the citizens, and national wealth.

Under sovereignity, territorial integrity is understood, which covers airspace and waters as well. Sovereignity can be endangered only by human factors: foreign armed forces, violent groups, or other offensive forces. Every threat against the citizens is also the subject of security, which can be caused by military or other human or non-human factors. This can endanger the lives of citizens, the society or the whole civilization. The third category contains threats against national wealth, which includes infrastructure, natural environment, cultural values, and important services.

Based on the above, this paper tries to use a broader definition for the term home defense. Accordingly, home defense covers all organizations, activities, and other relevant factors that have a well-defined goal of defending the security of the state, recovery and fighting the threats, consisting of military and civil elements. The military element is made up by the army and law enforcement agencies (e.g. police), the civil element includes defense management, strategic resources and other civil defense organizations. [8] In summary, disaster management is part of the home defense, under civil defense management.

Based on the above, it can be stated that the purpose of disaster management activity is to prepare for emergencies, hazard elimination, remediation, and recovery. Emergency can be caused by three types of events: [9]

- natural disaster like flood, inland water, snow, weathear phenomenon, or geological hazards (earthquake, forest fire);

- civilization-origin disaster like industrial accident, dangerous materials, waste pollution;

- other-origin disaster like epidemic, water pollution, critical infrastructure.

Different emergency situations are the subject of disaster management, so the scope of activities can be sorted based on them. The purpose of practice is defined by Mógor: [10]

- prevention of emergence;

- eliminating the causes;

- reducing harmful effects;

- defense of the citizens' lives and wealth;

- ensuring basic living conditions on the disaster area;

- recovery.

Based on this list, it can be stated that the disaster practice covers all processes related to disasters, so disaster management activity means a complex task system. Based on this division, it consists of the following actions:

- planning, organizing, synchronizing;

- implemention, controlling;

- installation, operation;

- informing, alarming; providing data;

- supervision. 
Although disaster management differs from country to country, it has different connection network, the subdivision above defines the national practice all over the world.

The last point of this chapter is defining disaster management as a science. Alexander [11] gives seven approaches to disasters: geography, anthropology, sociology, development studies, health sciences, geophysical sciences with engineering, and social psychology. Here, it can be seen that the science of disaster management is a broad, complex science which requires an interdisciplinary knowledge.

However, the aim of disaster science is not only communicating our research and knowledge, the communication, knowledge sharing and cooperation is also needed between the actors in disaster management. These actors include three types: scientific experts, policy makers and practitioners. Scientific experts need an interdisciplinary knowledge, they have to produce scientific results and advices to politicians and practitioners, moreover, they are responsible for innovations in disaster relief. For policy makers there are two main challenges: obtaining timely advice during emergency management and obtaining reliable advice for policy making. The practitioners are responsible for solving global and local disaster-related problems, for working on a more effective communication on risk and creating clear public partnerships. [12]

This paper gives a try to define disaster science and management. It is at the frontier of three main disciplines: political science, public administration science, and technical science.

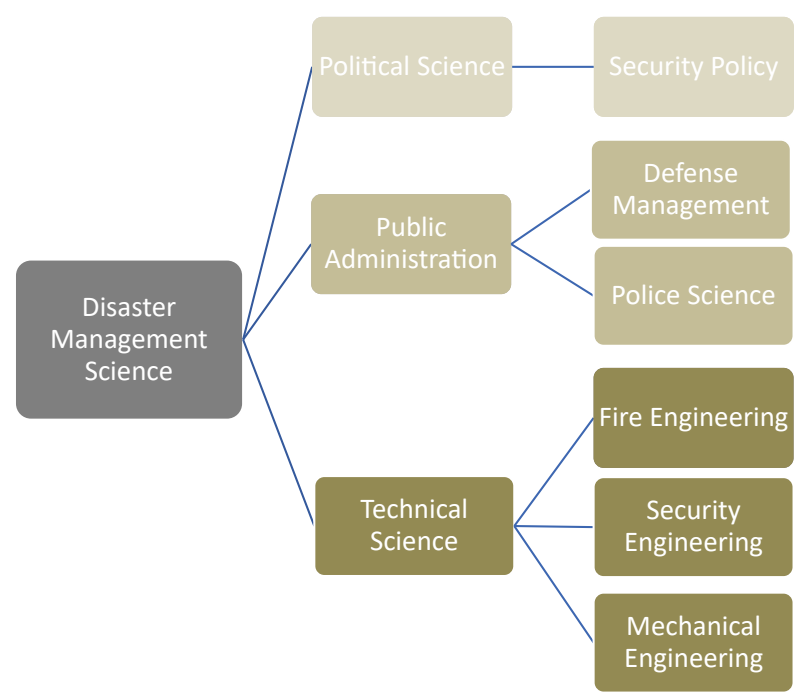

Figure 1. Scientific classification of disaster management.

[Created by the author.]

Under political science, security policy deals with disasters and emergencies, especially with their theoretical issues. Formerly, the science of security policy investigated only military security, where the subject of security was limited to the states and their offensive and defensive capabilities. In this approach, the role of the state was only the protection of its territory, airspace and population. According to the exceed security concept, other 
meanings are also distinguished: inter alia political, economical, social, and environmental security.

Political security is equal to sovereignity, which occurs on the level of political leadership, so the subject is legitimation, ideology and international judgement. In an economical dimension, the objects of threat are resources and funds related to society's well-being. Social security deals with language, culture, religion, national identity, tradition, habits. The last category is the environmental security, where disaster management takes place. Here, the subject of investigation is the protection of the biosphere of the planet (or the state in a narrow sense). This includes every change which endangers the living conditions of the population or the society in a direct or indirect way. In this ecological sector disaster management is affected by all questions, as the environmental security covers all environmental dangers. [13]

The categorization of the science of public administration is more difficult, because - as a new research area-there is no general accepted circumscription. Political philosophy started investigating issues related to public administration quite early-from the $19^{\text {th }}$ century, so a lot of definition was created, however, as the modern science it became part of university education relatively late. Broadly understood, public administration covers all topics which deal with the connection between political power, burecracy and the society (virtually every aministration issue). [14] This discipline has two relevant subdisciplines related to disaster management: defense management and police science. Defense management's research area is the defense of the population, and other defense issues related to the population: organization theory and practice, public management, humane resource management, leading management. Police science's definition is a difficult question as well, although according to Kersten, the police science' task is every state-level, local, or citizens' intention, activity, and attitude related to public order and security. [15] So, disaster management aspects of police science are: civil protection and coordination tasks. Based on the above, disaster management aspect of public administration covers-unlike security policy_practical areas of disaster management.

The third relevant category is technical science, within that fire engineering, security engineering, and mechanical engineering. Fire engineering is a part of civil engineering, its main areas are infrastructure, planning of buildings and fire prevention systems, so it supports the fire and industrial security within disaster management. Security engineering includes planning of alarm and protection systems, so its main task is building and developing disaster alert system. The most relevant area of mechanical engineering is planning and maintaining the toolkit of disaster management.

Nevertheless, we have to mention the auxiliary sciences of disaster management. First of all, other technical sciences belong here, where the main areas are environmental, conservation, water management, vehicle, and agricultural engineering. Jurisprudence plays an important role in creating and analyzing law, rules, rights and obligations related to disaster management. Psychology's research interest is coordination of the society, trauma and experience processing after emergencies. Media science has become indispensable through public informing during disasters. Meteorology as an auxiliary science ensures forecasting natural disasters and supporting preparation. Pedagogy plays also an important role, through training in schools and training of disaster relief personnel. Naturally, this list could be continued, this chapter tried to enumerate only a few of the most notable ones. 
At a global level, science and technology will play a central, more important role in disaster management, so specifying the state-of-the-art is essential. The disaster management science's importance is outstanding in the 2030 Agenda for Sustainable Development and other international agreements addressing Disaster Risk Management. In conclusion it can be stated, that the science of disaster management needs a comprehensive, interdisciplinary approach, as its experts come with various, multicoloured background. Disaster science has to provide science-based advice for disaster management policy-makers and practitioners, as well as scientific-based analysis for preparedness and response coordinating activities. [16]

\section{Analysis Levels of Disaster Management Organization}

As described above, the science of disaster management does not have a unified theoretical framework which could provide analytical method for examining its main fields. The international literature usually describes the national organization of a country, and it applies an appropriate framework which suits the given country's structure. ${ }^{2}$ In other cases, [20] when the author strives for a general introduction, the disaster relief process is being presented, not the general trends of disaster management structure. Thus, a general analytical framework of structure is subordinated in the international literature.

When disaster management is discussed as a state-level organization, the following problem is faced immediately: plenty of countries-especially among the developing ones-does not have an integrated countrywide institution, sometimes a general disaster management strategy is also missing. The build-up of a system of disaster relief can be dated in the middle of the $19^{\text {th }}$ century [21] — and due to developing differences, it extremely differs from country to country. Nevertheless, if a state does not have a central coordinating body, it still has some level of infrastructure and practice in fighting disasters.

In the following, an organizational model will be introduced, which can be applied to disaster management structure of all countries and provides a point for analyzing them. Due to deficiencies in some countries mentioned above, deficient levels can be found, or-in exceptional cases - the whole level could be missing. However, the model as a whole can be applied in those cases, too. The analysis of disaster management as an organization can be interpreted in four levels: mega-, macro-, meso-, and microstructure. The differentiation of the individual levels is based on their different function during relief.

Megastructure indicates the highest level of emergency management; the legal framework is meant here. Constitutional aspects of disaster management and civil defense, laws, regulations, government or ministerial level boundaries, provincial, county, local, and other, grass-roots handlers belong here. Apart from this, all the international foundations, treaties, hostages, and the provisions ratified by the state are included. In its intensity, the level extends to all written document which governs disaster prevention actions.

The next level is the level of macrostructure, the political level in other words. This includes all disaster management actors at the level of political decision-making. Primarly,

For example, Mógor [17] goes by a method which can be used only in Hungary’s case, Hanny’s [18] method only in China's case, and the analysis of the Japanese Prime Minister's Office [19] shows specialities of the Japanese structure. 
ministries, departments, divisions, experts, and secretaries are covered, which control and coordinate the bigger or smaller field of emergency management. If there is a central coordinating body which controls disaster-related organizations at all levels, those are also part of the macrostructure, as being the subject of political leadership owing to their extensive responsibilities. That is to say, the level of macrostructure contains the central management, its controllers, and affiliated officers of the state.

The level of mesostructure is the core of disaster relief. It consists of all organizations, facilities and units involved in preventive, remedial, defective and planning processes of actual disaster management activities. At that level, fire departments, civil protection organizations, meteorological services, industrial security organizations, coastal guard, civilian police, police officers, military, rescue units, volunteer units are discussed, which are taking up the task of deconstruction. Research institutes, monitoring centers that participate in preventive, controlling, and coordinating processes, or any disaster response council (provincial, county, municipal) under the national level, belongs to the level of the mesostructure. The majority of papers, documents and books, which discuss state-level disaster management, carry out their research at the level of macro- and mesostructure.

Microstructure is the smallest, but most varied level, this is the society-related aspect of emergency management, practically, every human resource-related phenomenon belongs here. Due to its wideness, the spectrum of analysis is quite extensive and the elements can be the following: public information system and informing practice, school education, material of the university training, framework and possibilities of training, social perception, cultural embedding, disasters-related folk traditions. Since this level does not cover a specific organizational unit, we can not undertake in a study to discuss all aspects of this level. In a comprehensive work, it is reasonable to focus only on training and information-alert elements of disaster relief.

\section{Disaster Management Activity}

In this chapter, the concept of disaster management activity will be introduced based on relevant international literature. Unlike the organizational structure, international organizations and researchers choose the aspect of activity when analyzing disaster management with a general intent. At international disaster science, two structures are applied, which in this paper will be called vertical and horizontal aspects. At vertical level, the individual disaster types and their special relief methods are discussed, its question is: against what? In case of horizontal level, the linear process is the subject of investigation, the describing of the state-level disaster management cycle is the target. Its question is how?

In the negotiation of the vertical level, over the analysis of each type of disaster, possible special prevention, prevention and preparation processes need to be included as well. There are several principles for defining each group: the origin of the disaster, the magnitude of the damage, and the quality of the necessary measure. The most applied division is the International Federation of Red Cross and Red Crescent Societies' one which follows categorization by origin. Accordingly, two disaster types are distinguished: natural and technological (also known as human origin) ones. 
Within natural disasters, geophysical (earthquakes, landslides, tsunamis and volcanic activity), hydrological (avalanches and floods), climatological (extreme temperatures, drought and wildfires), meteorological (cyclones and storms/wave surges) or biological (disease epidemics and insect/animal plagues) can be differentiated. Technological ones include environmental degradation, pollution and accidents, technological or man-made hazards (complex emergencies/conflicts, famine, displaced populations, industrial accidents and transport accidents). [22]

The systematization of Dey and Singh is more thorough than the classification of the Red Cross, its approach also uses the aspect of the disaster's origin.

Table 1. Types of Hazards. [23]

\begin{tabular}{|l|l|l|}
\hline Types & Hazards \\
\hline Geological & 1. Earthquake & 4. Landslide \\
& 2. Tsunami & 5. Dam burst \\
& 3. Volcanic eruption & 6. Mine fire \\
\hline Water \& climatic & $\begin{array}{l}\text { 1. Tropical cyclone } \\
\text { 2. Tornado and hurricane }\end{array}$ & $\begin{array}{l}\text { 6. Cloudburst } \\
\text { 7. Landslide } \\
\text { 3. Floods }\end{array}$ \\
& $\begin{array}{l}\text { 4. Drought } \\
\text { 5. Hailstorm }\end{array}$ & $\begin{array}{l}\text { 9. Snow cold wave } \\
\text { 10. Sea erosion }\end{array}$ \\
\hline Environmental & 1. Environmental pollutions \\
& 2. Deforestation & $\begin{array}{l}\text { 3. Desertification } \\
\text { 4. Pest infection }\end{array}$ \\
\hline Biological & 1. Human/animal epidemics & 3. Food poisoning \\
& 2. Pest attacks & 4. Weapons of mass destruction \\
\hline Chemical, industrial & 1. Chemical disasters & 3. Oil spills/fires \\
and nuclear accidents & 2. Industrial disasters & 4. Nuclear accidents \\
\hline Accident related & 1. Boat/road/train accidents/ & 3. Building collapse \\
& air crash, rural/urban fires, & 4. Electric accidents \\
& bomb/serial bomb blasts & 5. Festival related disasters \\
2. Forest fires & 6. Mine flooding \\
\hline
\end{tabular}

Disaster types can be categorized according to their peril, though this classification may vary considerably between countries and regions. The figures below were made by the author based on the data of The International Disaster Database, aiming to illustrate the danger of disasters. Figure 2 shows deaths caused by disaster types worldwide. 


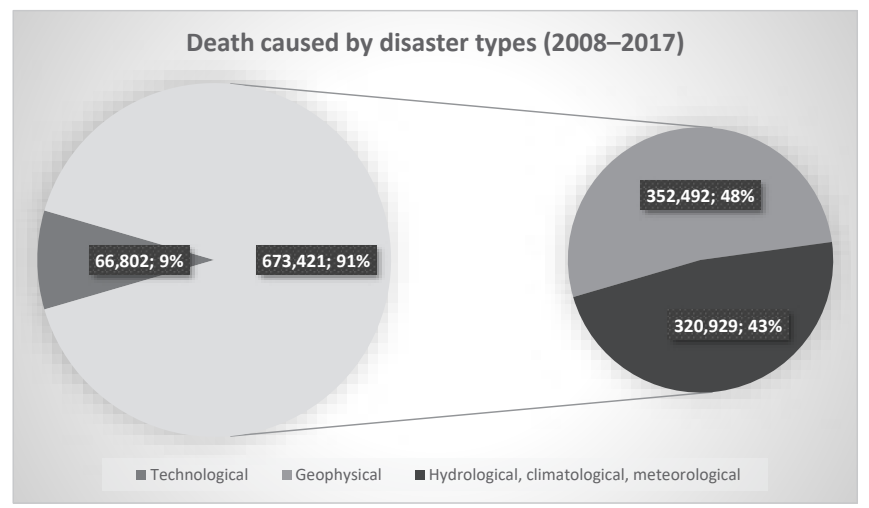

Figure 2. Deaths caused by individual disaster types (2008-2017).

(Created by the author based on [24].)

As it can be seen, in the period from 2004 to 2013, disasters of technological origin had the least victims, with traffic accidents $(45,810)$ in the majority. $91 \%$ of the deaths were caused by natural disasters, mainly geophysical types. Within geophysical disasters there are almost entirely tsunamis and earthquakes, and as they often occur at the same time, the deaths of both have been registered $(351,817)$ the most. The most dangerous type among natural ones was the category of climatological, meteorological and hydrological disasters, the most relevant ones were wind storms $(166,123)$ and extreme temperature $(73,568$ persons).

On Figure 3, the same categories are shown, although it is based on the magnitude of damage in million dollars caused by the disaster:

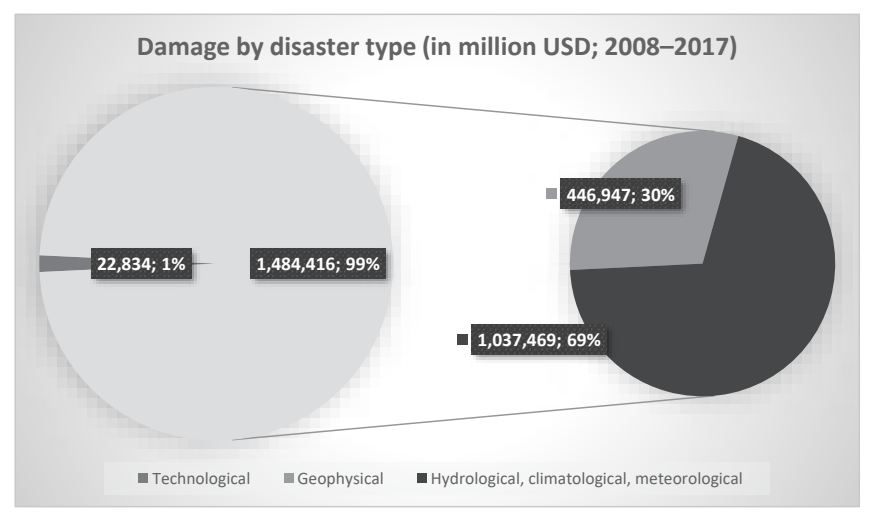

Figure 3. Magnitude of damage by disaster types (in million USD, 2008-2017).

(Created by the author based on [24].)

Figure 3 also accounts for the damage occurring over the nine-year period starting in 2004. The rate between technological and natural disasters is similar to before (the danger of natural disasters is overwhelming), but the rate of technological disasters has dropped from 
$9 \%$ to $1 \%$. In case of disasters with natural origin, however, the rate has been reversed, the damage caused by geophysical disasters is $30 \%$ as the number of all disasters. Almost all the damage caused by geophysical disasters (USD 446.05 billion) was caused by earthquakes and tsunami. In the other category, wind storms (USD 544.70 billion) and floods (USD 358.42 billion) can be classified as rather dangerous ones.

The other level of disaster management activity is the horizontal level, in other words, the disaster management cycle. According to Corina Warfield "the Disaster management cycle illustrates the ongoing process by which governments, businesses, and civil societies plan for and reduce the impact of disasters, react during and immediately following a disaster, and take steps to recover after a disaster has occurred.” [25] Its three main phases are: pre-disaster, emergency response, and post-disaster ones.

The pre-disaster phase is primarily aimed at risk reduction and preparation. At this stage, besides disaster management organization, the active contribution of political decision-making, executive power, and smaller, provincial, and municipal governments are needed. Creating a legal background is essential for the development of a successful defense system, which although belongs to the public policy, the professional background is provided by disaster management. Preventive measures include all monitoring activities which collect and analyze data about risk and vulnerability, they serve as a basis for defense measures and relief models. In conlusion, the pre-disaster phase contains all measures which support the development of defense task system, also including training, education and planning the alarm system. [26]

The emergency response section can be divided into two additional units: primary and long-term intervention. Most of the steps and measures planned in the pre-disaster phase are fulfilled in this one. In the primary phase, local organizations intervene and act according to their pre-agreed principles and action plans, the central body and the political body are collecting data, evaluating the event and determining additional measures. As part of the long-term phase, the problem gets explored, the compensation gets defined and ordered. The central organization is responsible for the provision of special emergency rescue tasks and organizes the civil defense tasks (protection of the population, supply of food and drinking water, medicine supply, trauma management). The duration of emergency response phase is short, up to a few weeks. [27]

The post-disaster phase's main task is restoration and reconstruction, rehabilitation of the population's condition, reparation of the damage and rebuilding the infrastructure. The aim is to reach a pre-disaster status or a higher level of welfare, which means re-establishing the information system, education system, public administration, economic infrastructure, and stability. This phase also includes lessons learned, evaluation of data, and the foundation of the development strategy that anticipates preparation and prevention. Quick recovery can take months to months, while full reconstruction for up to years. [27]

\section{Levels of Disaster Management Analysis}

In order to be able to resemble individual state-level disaster management organizations in a scientifically modest way, an analysis of an elementary aspect is required. Each level of examination has been designed to make a broad comparison possible through the analyzed 
data. Elements of analytical levels and critical elements are summarized by the following outline. When editing, the author used Rihmer's lexicographical work [28] as an initial point.

\section{Possible aspects of state-level analysis of disaster management (outline)}

\section{Information about the country (background)}

a) Geographical feature of the country, broadly the region, possible environmental risk factors:

- natural environment: large footprints, mountains, deserts, rivers, coasts, features of weather phenomenon (rain, drought, temperature);

- social-economical environment: distribution of population, urbanization, industrialization, infrastructural facilities.

b) Relevant disaster types:

- categorization by frequency, economic damage, and affected people;

- presenting specific, typical disaster types of the region.

II. Analysis of the system

c) Megastructure (legal framework):

- appropriate sections of constitution, law, decrees;

- international contracts, statutes;

- action plans, strategy.

d) Macrostructure (political level):

- ministries, state organs, subordinate organs, divisions, specialists, ministers, politicians and referents who are responsible for the whole or a part of emergency management;

- central, coordinating body (if any).

e) Mesostructure (practical units):

- fire-fighters, civil defense organizations, meteorological services, industrial security organizations, coastguards, police, gendarmerie or military personnel, rescue units, voluntaries, research centers, agencies, think-tanks, advisory offices.

f) Microstructure (social aspects):

- informing organizations, media;

- educational institutes, offices responsible for training the society;

- disaster awareness in the society;

- cultural phenomenon, habits, beliefs, traditions, folktales;

- other social phenomena related to disasters and emergency management.

III. Analysis of activity

g) Vertical level (against what?):

- characteristics of coping with disaster types;

- special challenges and methods.

h) Horizontal level (how?):

- applying disaster management cycle to the country;

- each phase, practical application of plans. 
IV. Qualitative analysis

i) Presenting the actual disaster relief through a case study;

j) Experiences based on fieldwork and observation;

k) Criticism of practical operation.

Naturally, this system can be expanded, according to new challenges and hazards.

\section{Summary}

The purpose of the author was to set up an analysis model for presenting and analyzing state-level disaster management organizations and their activity. The created framework is useful for only a general description of a country's emergency management; a detailed analysis is possible only with further enlargement. The proposed levels interpret disaster management from two aspects: as an organization and as an activity.

It is advisable to begin the analysis with a generic country presentation; accordingly, the geographical features and typical disasters of the region should be presented. The country system can be examined at four levels, which gives the mega-, macro-, meso- and microstructure level. The actions can be analyzed on two axes, which is displayed in a vertical and horizontal dimension. The analytical earnings are suggested by a case study or some other criterion criticism that emphasizes the presentations, organizations, and action plans presented earlier, and can therefore serve as a basis. At the end of the analysis, a case study or other criticism is suggested which supports the practical application of previously presented institutions, organizations and action plans and can serve as a basis for evaluation.

The various domestic disaster management sciences' primer purpose is to support its own state-level system and activity. For efficient work, however, the knowledge of international scientific methods and experiences are indispensable, by which the individual domestic processes can evolve. In this sense, the number of international disaster research will hopefully grow, this paper would like to join them as well.

\section{Acknowledgement}

Supported BY the "ÚNKP-17-3-2-NKE-9 code ÚNKP - New National Excellence Program of the Ministry of Human Capacities”.

\section{References}

[1] KUTI R., FÖLDI L.: Extreme weather phenomena, improvement of preparedness. Hadmernök, 73 (2012), 60-65.

[2] KUTI R., NAGY A.: Weather Extremities, Challenges and Risks in Hungary. Academic and Applied Research in Public Management Science, 144 (2015), 299-306. 
[3] About disaster management. International Federation of Red Cross and Red Srescent Societies. www.ifrc.org/en/what-we-do/disaster-management/about-disaster-management/ (Downloaded: 31.08.2017)

[4] BLANCHARD, W.: Guide to Emergency Management and Related Terms, De initions, Concepts, Acronyms, Organizations, Programs, Guidance, Executive Orders \& Legislation. A Tutorial on Emergency Management, Broadly Defined, Past and Present, 2008. http:// training.fema.gov/EMIWeb/edu/docs/terms\%20and\%20definitions/Terms\%20and\%20 Definitions.pdf (Downloaded: 22.09.2017)

[5] ETKIN, D.: Disaster Theory. Amsterdam: Elsevier, 2016. https://doi.org/10.1016/ B978-0-12-800227-8.00002-8

[6] SZABÓ J. (szerk.): Hadtudományi Lexikon. Budapest: Magyar Hadtudományi Társaság, 1995.

[7] DEÁK A.: Biztonságpolitikai kézikönyv. Budapest: Osiris, 2007.

[8] ISASZEGI J. (szerk.): Magyarország védelmi igazgatása a közigazgatás új környezetében. Budapest: HM Zrínyi Nonprofit Kft. - Zrínyi Kiadó, 2014.

[9] ETKIN, D.: Disaster Theory. Amsterdam: Elsevier, 2016.

[10] MÓGOR J.: Katasztrófavédelemins. Budapest: CompLex Kiadó, 2009.

[11] ALEXANDER, D.: Confronting Catastrophe. Washington D.C.: Terra Publishing, 2000.

[12] CLARK, I., de GROEVE, T., MARÍN FERRER, M., POLJANŠEK, K., FAIVRE, N., PETER, D., QUEVAUVILLER, P., BOERSMA, K. E., KRAUSMANN, E., MURRAY, V., PAPADOPOULOS, G. A., SALAMON, P., SIMMONS, D. C., WILKINSON, E., CASAJUS VALLES A., DOHERTY B., GALLIANO, D.: Future challenges of disaster risk management. Chapter 6. In. POLJANŠEK, K., MARÍN FERRER, M., de GROEVE, T., CLARK, I. (eds.): Science for disaster risk management 2017: knowing better and losing less. Luxembourg: Publications Office of the European Union, 2017.

[13] GAZDAG F. (szerk.): Biztonsági tanulmányok - Biztonságpolitika. Budapest: Zrínyi Miklós Nemzetvédelmi Egyetem, 2011.

[14] Public Administration: An Art or a Science. Management Study Guide. http:// managementstudyguide.com/public-administration-an-art-or-science.htm (Downloaded: 19.10.2017)

[15] KERSTEN, J.: Was versteht man unter „Polizeiwissenschaft“ - Eine programmatische Standortbestimmung. Neue Kriminalpolitik, 241 (2012), 8-10.

[16] BOWER, A., BLOCK, J., DALI, M., FAIVRE, N., FELL, T., GHISLAIN, P., HAPPAERTS, S., KAVVADAS, I., KOCKEROLS, P., MOLNAR, A. M., QUEVAUVILLER, P., VILLETTE, F.: Current status of disaster risk management and policy framework. Chapter 1. In. POLJANŠEK, K., MARÍN FERRER, M., de GROEVE, T., CLARK, I. (eds.): Science for disaster risk management 2017: knowing better and losing less. Publications Office of the European Union, Luxembourg, 2017.

[17] MÓGOR J.: Katasztrófavédelem. Budapest: CompLex Kiadó, 2009.

[18] HANNY Á.: Katasztrófavédelem a Kínai Népköztársaságban. Budapest: Tajvani Véndiákok Magyar Egyesülete, 2013. http://mytaiwan.hu/wpcontent/uploads/2013/12/Hanny-\%C3\% 81kos-Akatasztr\%C3\%B3fav\%C3\%A9delem-a-K\%C3\%ADnai-N\%C3\%A 9pk\%C3\%B6zt \%C3\%A1rsas\%C3\%A1gban.pdf (Downloaded: 22.09.2017)

[19] 内閣府：日本の災害対策. 日本の内閣府 Tokyo, 2015.

[20] KHAN, H., VASILESCU, L. G., KHAN, A.: Disaster Management Cycle - a Theoretical Approach. Management and Marketing Journal, 61 (2008), 43-50. 
[21] SZILÁGYI J., SZABÓ K.: A tüzrendészet fejlődese az őskortól a modern időkig. Budapest: BM Könyvkiadó, 1986.

[22] Types of disasters: Definition of hazard. International Federation of Red Cross and Red Crescent Societies. www.ifrc.org/en/what-we-do/disaster-management/about-disasters/ definition-of-hazard/ (Downloaded: 23.08.2017)

[23] DEY, B., SINGH, R. B.: Natural hazards and disaster management. Delhi: Natural Hazards and Disaster Management, 2006.

[24] GUHA-SAPIR, D., BELOW, R., HOYOIS, Ph.: The CRED/OFDA International Disaster Database. Brussels: Université Catholique de Louvain. www.emdat.be (Downloaded: 17.01.2018)

[25] WARFIELD, C.: The Disaster Management Cycle. Kóbe: The Global Development Research Center. www.gdrc.org/uem/disasters/1-dm_cycle.html (Downloaded: 05.09.2017)

[26] PAPP B.: Állami szintű katasztrófavédelem elemzési szempontjai nemzetközi környezetben. Védelem Tudomány 21 (2017), 263-284.

[27] KHAN, H., VASILESCU, L. G., KHAN, A.: Disaster Management Cycle - a Theoretical Approach. Management and Marketing Journal, 61 (2008), 43-50.

[28] FÓRIS Á., RIHMER Z.: A szótárak minősítési kritériumairól. Fordítástudomány, 91 (2007), 109-113. 